\title{
RUNOFF AND SOIL EROSION CHARACTERISTICS IN DIFFERENT PERIODS OF AN INTENSIVE FOREST MANAGEMENT SYSTEM IN A TROPICAL INDONESIAN RAINFOREST
}

\author{
H. SURYATMOJO ${ }^{1}$, M. FUJIMOTO ${ }^{2}$, K. KOSUGI $^{3} \&$ T. MIZUYAMA ${ }^{3}$ \\ ${ }^{1}$ Laboratory of Watershed Management, Faculty of Forestry, Gadjah Mada University, Indonesia. \\ ${ }^{2}$ Educational Unit for Adaptation and Resilience for a Sustainable Society, Center for the Promotion of Interdisciplinary \\ Education and Research, Kyoto University, Japan. \\ ${ }^{3}$ Laboratory of Erosion Control, Division of Forest and Biomaterials Science, Graduate School of Agriculture, \\ Kyoto University, Japan.
}

\begin{abstract}
Tropical Indonesian rainforest is managed using an Intensive Forest Management System (IFMS). The main activity is selective logging for timber harvesting and intensive line planting to enrich the standing stock. These activities significantly alter the forest canopy cover and the hydrologic response of catchments, including peak discharge, direct runoff and soil erosion. Understanding the hydrologic effects in an IFMS is helpful to develop a forest management strategy. This study investigated the impact of vegetation changes on runoff and soil erosion characteristics in different periods of an IFMS resulting from their respective forestry treatments. This study was conducted in a natural tropical rainforest at Bukit Baka Experimental Catchment, Central Kalimantan, Indonesia. Runoff and soil erosion characteristics were investigated in three small catchments, a virgin forest catchment (C1), a 10-year-old line plantation catchment (C2) and a 1-year-old line plantation catchment (C3). The IFMS has increased in large scale of open forests and exposed the bare soil, especially in the early years after forest operation. This condition has changed drastically in the catchment hydrologic responses. The increase in discharge, direct runoff, and suspended sediment discharge in the $\mathrm{C} 3$ was higher than those in the $\mathrm{C} 2$ and $\mathrm{C} 1$, particularly for large rainfall events. The proportion of annual rainfall as water yield in the $\mathrm{C} 1, \mathrm{C} 2$, and $\mathrm{C} 3$ was 27,30 , and $41 \%$, respectively. The annual suspended sediment yield in the $\mathrm{C} 1, \mathrm{C} 2$, and $\mathrm{C} 3$ was $0.15,3.6$, and $14.9 \mathrm{tha}^{-1} \mathrm{y}^{-1}$, respectively. The results showed that the magnitude of runoff and soil erosion depends on the interaction among the rainfall, forest cover changes, forest treatment applied and catchment characteristics. Ten years after forest operation, forest cover has recovery close to natural condition, but still there are differences in hydrological response. Controlling soil erosion during logging activities by reducing the impact of logging and combining ecologically based vegetation structure design is an effective way to control runoff and soil erosion.

Keywords: Direct runoff, intensive line planting, logged-over forest, peak discharge, selective logging, soil erosion, virgin forest.
\end{abstract}

\section{INTRODUCTION}

The rainforests that cover $60 \%$ of Indonesia comprise $10 \%$ of the total world tropical rainforest. A key resource of tropical rainforests is forest timber, but land conversion and timber extraction are threatening biodiversity and hydrologic responses. Tropical Indonesian rainforest is managed by an Intensive Forest Management System (IFMS), which commenced in 2002. The main activity of IFMS is selective logging for timber harvesting and intensive line planting to enrich the standing stock. Timber extraction using heavy machines destroys soil structure, which plays an important role in water and nutrient cycling, and accelerates soil erosion rates [1]. Heavy machines in timber collection areas and on skidder roads increase soil compaction by up to $40 \%$ of the natural condition $[1,2]$, and $10-30 \%$ of the soil surface may become bare due to logging roads, skidder tracks and log landings $[3,4]$. The use of heavy equipment tends to compact topsoil, setting in motion a negative spiral of reduced infiltrability and increased frequencies of overland flow and sheet erosion, thereby hindering the establishment of a new protective layer of vegetation and litter [4]. 
Different land-use practices affect soil infiltration rates in different ways depending on their effects on the intrinsic properties of the soil [5]. Additionally, selective logging and intensive line planting systems are suspected to dramatically impact soil properties. In a previous study, the infiltration capacity of a tropical rainforest 1 year after selective logging and intensive line planting treatment decreased to $81.8 \%$ that of a virgin forest [6]. The effect of human activities on runoff regimes has been demonstrated by several experimental studies in various parts of the world. Much research has focused on monitoring the influence of changes in land cover, mainly deforestation and afforestation processes [7-11], the influence of cultivated areas [12-14] and the impact of logging [15-18].

Runoff responses and soil erosion rates are significantly different with changes in land cover. Many studies have considered runoff and soil erosion in tropical forests around the world $[4,8,14-17,19-21]$. In Southeast Asia with its great geological diversity, the study of runoff and erosion in tropical forests is dominated by research in Thailand and Malaysia but is very limited in Indonesia. Rainfall intensity in the tropical rainforests on Kalimantan Island, Indonesia, is high; therefore, hydrologic responses such as peak discharge, direct runoff, water yield, and soil erosion can potentially become problems when land use or forest cover changes. The IFMS is a unique system that was developed solely for Indonesian tropical forest. The main activities covered by the IFMS are selective logging and intensive line planting. Several studies have investigated the rainfall-runoff-erosion in Kalimantan, Indonesia [18,22-25]. Research concerning the IFMS in tropical Indonesian rainforest is still limited [25]. Therefore, a need exists to investigate the hydrologic response of tropical rainforests managed under an intensive management system. This study investigated the impact of vegetation changes on runoff and soil erosion characteristics in different periods of an IFMS resulting from their respective forestry treatments. Thus, this paper reports the results of an analysis of the hydrologic response of peak discharge, direct runoff, water yield, and suspended sediment yield (SSY) among three small forested catchments: an undisturbed (virgin) forest, a 10-year-old intensive line plantation, and a 1-year-old intensive line plantation.

\section{METHODS}

\subsection{Study site}

The study was conducted in tropical rainforest at Bukit Baka Experimental Catchments, which is located in the headwater region of the Katingan watershed, one of the largest watersheds in Central Kalimantan (Fig. 1a). The site is in Sei Seruyan block of the Sari Bumi Kusuma concession area, a private forest company in Central Kalimantan, Indonesia $\left(00^{\circ} 36^{\prime}\right.$ to $01^{\circ} 10^{\prime}$ south latitude and $111^{\circ} 39^{\prime}$ to $112^{\circ} 25^{\prime}$ east longitudes) (Fig. 1b). The Katingan watershed has a total catchment area of 1,908,297 ha, and the length of the main river is $650 \mathrm{~km}$. This location is approximately $400 \mathrm{~km}$ northwest of Palangka Raya, the provincial capital of Central Kalimantan, and approximately $500 \mathrm{~km}$ east of Pontianak, the provincial capital of West Kalimantan. The forest cover in this watershed includes $1,179,985$ ha or $61.83 \%$ of the total area, most of which is found in the headwaters. This upstream catchment is a hilly region with altitudes of $150-1,278 \mathrm{~m}$ above the sea level.

The mean annual precipitation during 2001-2012 was 3,631 mm, with the highest average monthly precipitation $(367 \mathrm{~mm}$ ) occurring in November and the lowest average monthly precipitation $(183 \mathrm{~mm})$ in August. According to the forest climate classification system of Schmidt and Ferguson [26], the area is a type A (very wet) tropical rainforest (monthly average rainfall $>100 \mathrm{~mm}$ ). 


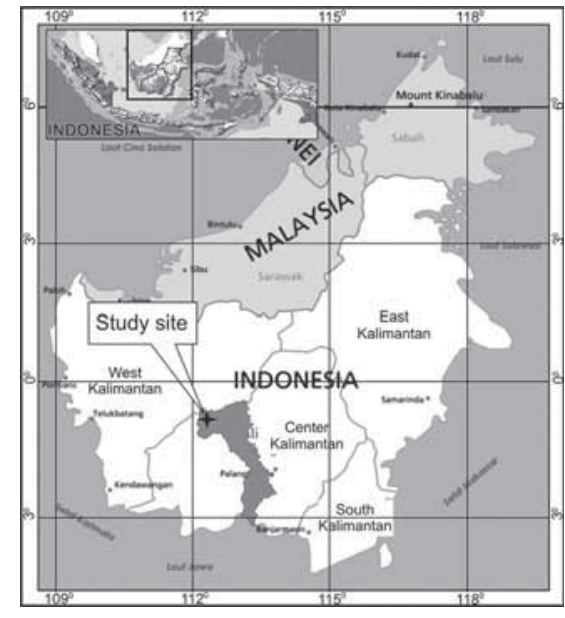

(a)

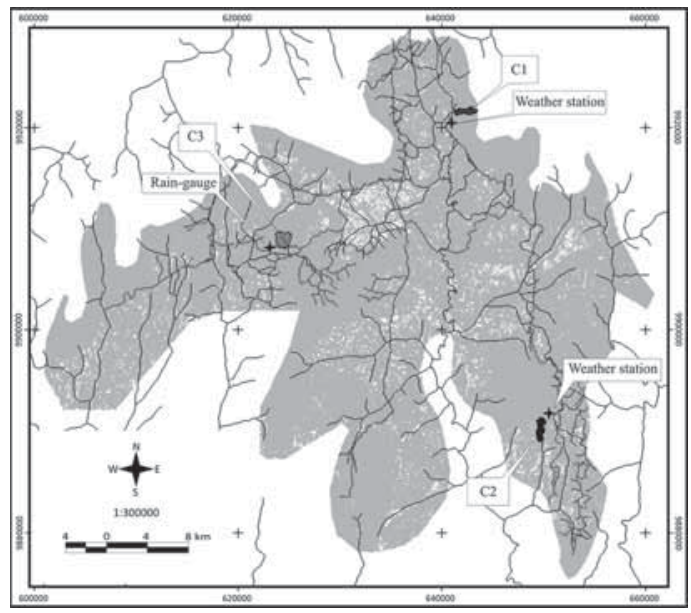

(b)

Figure 1: Research location. (a) Study site in the headwaters of the Katingan watershed, Central Kalimantan. (b) Experimental catchments in the Sari Bumi Kusuma concession area.

The number of rainy days varies from 95 to 112 days, and the mean temperature is $30-33^{\circ} \mathrm{C}$ at noon and $22-28^{\circ} \mathrm{C}$ at night [25]. Based on Forest Type Classification map, the study site was classified located in the tropical lowland rainforest with similar forest vegetation characteristics in structure and species distribution. The vegetation in Kalimatan is dominated by Shorea spp., Eugenia spp., Eusideroxylon zwageri, Shorea laevis, Calophyllum inophyllum, Litsea firma, Anthocephalus chinensis, Macaranga hypoleuca, Durio lissocarpus, and Octomeles sumatrana. The average number of trees in this natural forest is 228 per hectare [25]. Based on the systematic geological map, the three catchments were located in the same geological type as Pinoh Metamorphics with muscovite-quartz schist, phyllite, slate, kornfels, and some metatuff and quartzite; andalusite, cordierite, and biotite in places; and only rare deposits of sillimanite and garnet. The soil was classified as Ultisol and remains continuously moist [27]. Ultisol is the most weathered type of soil, and it shows the ultimate effects of leaching. Ultisol is characterized as a mineral soil with a $\mathrm{B}_{2}$ horizon containing $20 \%$ more clay than the upper $\mathrm{B}_{1}$.

\subsection{IFMS}

IFMS is a silviculture technique to maintain the potency of forest standing stock. The main activities are selective logging and intensive line planting. The IFMS system includes selective logging operation of trees with diameters up to $40 \mathrm{~cm}$ (Fig. 2a-c) and intensive line planting system with line clearing of 15-20\% of the forested land to enrich the standing stock (Fig. $2 \mathrm{~d}$ and e).

About 200 seeds per hectare are typically planted, and the expected standing stock at the end of the rotation (30 years) is approximately $400 \mathrm{~m}^{3}$ per hectare, assuming 160 trees per hectare with an average diameter of $50 \mathrm{~cm}$ (or $2.5 \mathrm{~m}^{3}$ per tree) [28]. Selective logging and line clearing for intensive line planting have increased the open area in the forest and decreased the forest canopy cover. The changes in forest canopy cover by the IFMS process are shown in Fig. 2. 


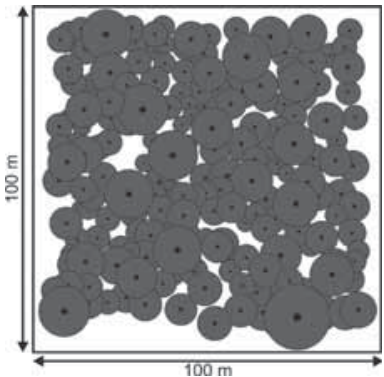

(a)

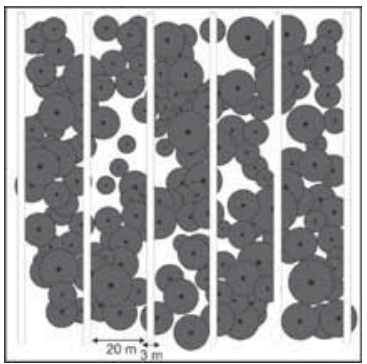

(d)

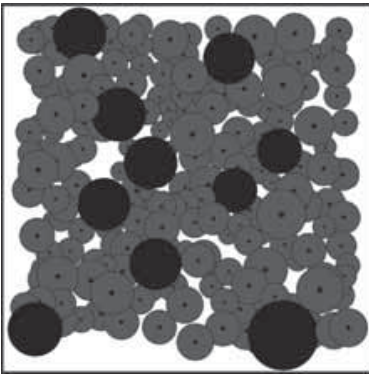

(b)

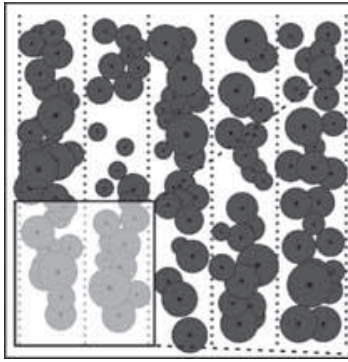

(e)

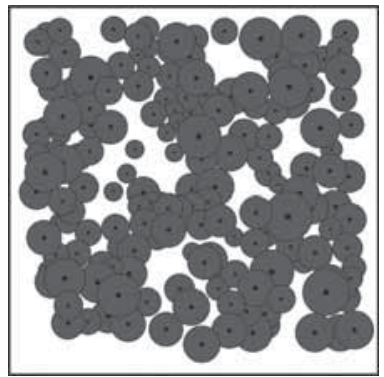

(c)

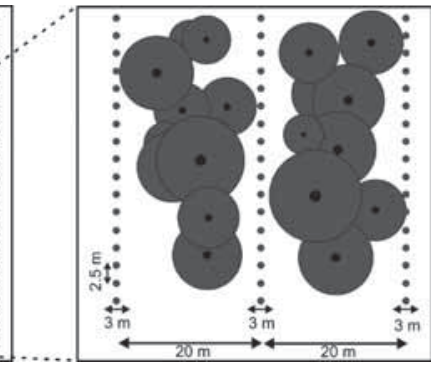

Figure 2. Changes in canopy tree cover due to the IFMS process. (a) Natural forest. (b) Trees selected for logging (denoted as black circle). (c) Canopy cover after selective logging. (d) Design of a clear-cutting line. (e) Canopy cover after the IFMS process.

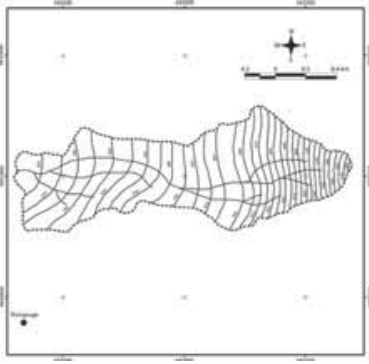

(a)

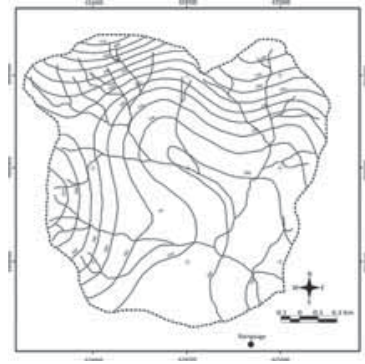

(b)

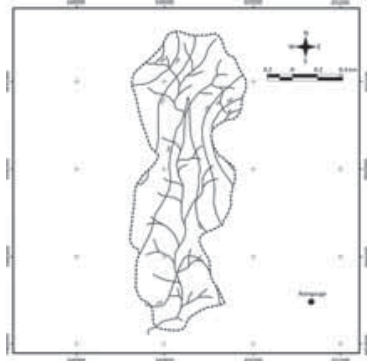

(c)

Figure 3: Research catchments: (a) C1, (b) C2, and (c) C3.

\subsection{Research catchment}

This research was conducted in an natural undisturbed forest (referred as C1) and two disturbed forest with IFMS operation (treated catchments) (Fig. 1b). The treated catchments were forest that had been selectively logged and intensively line planted in 1999 or 10-year after IFMS operation (referred as C2), and a forest that had been selectively logged and intensively line planted in 2008 or 1-year after IFMS operation (referred as C3). The research catchment maps are shown in Fig. 3. Physical characteristics are given in Table 1 [29]. 
Table 1: The relative material for different designs of a torsion anchor support.

\begin{tabular}{lcccccc}
\hline Catchment & $\begin{array}{c}\text { Drainage } \\
\text { area }\left(\mathrm{km}^{2}\right)\end{array}$ & $\begin{array}{c}\text { Catchment } \\
\text { circularitya }\end{array}$ & $\begin{array}{c}\text { Catchment } \\
\text { slope }(\%)\end{array}$ & $\begin{array}{c}\text { Drainage } \\
\text { density } \\
\left(\mathrm{km}^{2} \mathrm{~km}^{2}\right)\end{array}$ & $\begin{array}{c}\text { Main river } \\
\text { length }(\mathrm{km})\end{array}$ & $\begin{array}{c}\text { Main river } \\
\text { slope }(\%)\end{array}$ \\
\hline $\mathrm{C} 1$ & 1.10 & 0.22 & 11.36 & 3.30 & 2.0 & 12.48 \\
$\mathrm{C} 2$ & 1.49 & 0.26 & 5.49 & 6.05 & 2.4 & 8.65 \\
$\mathrm{C} 3$ & 1.91 & 70.4 & 5.1 & 5.76 & 2.1 & 4.85 \\
\hline
\end{tabular}

$R f=\frac{A}{L^{2}}$, where $A$ is the catchment area and $L$ the length of the catchment.

\subsection{Observations and analysis}

To clarify the characteristics of rainfall among three catchments, three automatic tipping-bucket rain gauges (logging time, $15 \mathrm{~min}$ ) were installed at each catchment and deployed near the outlet catchment. A Parshall flume and a water-level logger (HOBO U-20) with a time interval of 15 min were installed at each catchment outlet. The 2.5 -m flume width was divided into three cross sections, and the water discharge and suspended sediment was measured at each section. Water discharge was measured with a current meter. Suspended sediment was measured using a suspended sampler above the bed layer.

Rainfall events that have a single peak rainfall and a single peak runoff hydrograph shape for each catchment were analysed. A rainfall event is defined as the rainfall separated by non-rainfall periods of $24 \mathrm{~h}$ or longer. During 1-year observation period, the number of storm events used for paired hydrological analysis in the $\mathrm{C} 1, \mathrm{C} 2$, and $\mathrm{C} 3$ s were 35,46 , and 39 , respectively. The hydrograph analysis was undertaken by dividing the runoff into direct runoff and base flow using a straight-line method and then calculating the direct runoff volume for each hydrograph of each catchment. Direct runoff is the sum of surface runoff, subsurface flow, and channel interception. This is the part of the hydrograph of interest when floods and flood-producing characteristics of catchments are analysed. Soil erosion was calculated from the suspended sediment concentration (SSC) using the equal-discharge-increment (EDI) method [30]. The objective of the EDI method is to collect a discharge-weighted sample that represents the entire flow passing through the cross section by obtaining a series of samples, each representing equal volumes of stream discharge. The EDI method requires that the three criteria be met: samples are collected isokinetically; the vertical represents the mean concentration and particle-size distribution for the subsection sampled; and the discharges on both sides of the sampling vertical are predetermined proportions of the total discharge. The flume cross section was divided into three sections of equal discharge increments, and a sample was collected from the midpoint of each increment. An isokinetic depthintegrating sampler (modified US-DH-81 sampler with $600 \mathrm{ml}$ bottle sampler) was moved up and down at the same rate in a vertical direction across the flume, which allowed the sampler to integrate sampling in relation to depth and velocity at each vertical point. The volumetric sediment concentration $(\mathrm{mg} / \mathrm{l})$ was measured by the evaporation method [31]. The three catchments were analysed by comparing the direct runoff, peak discharge increase from base flow to peak discharge, annual water yield, and annual erosion yield to understand the hydrological impact of vegetation changes in the IFMS. 


\section{RESULTS}

\subsection{Forest canopy cover changes}

The IFMS changed the forest canopy cover. The profile of vegetation structure and composition was monitored in a permanent sample plot (PSP) in each catchment. PSP is a long-term observation site of forest growth, for measuring diameter increment, volume increment and stand structure dynamics. PSP uses 1 hectare square of forest area and is located in the middle slope of each catchment. In the PSP, forest vegetation was measured using a nested cover quadrats method. Each type of vegetation was measured at 25 subplots (total in 1 hectare). The subplot is classified into four types: $20 \times 20 \mathrm{~m}$ for tree; $10 \times 10 \mathrm{~m}$ for pole; $5 \times 5 \mathrm{~m}$ for sapling; and $2 \times 2 \mathrm{~m}$ for seedling. As shown in Table 2, there were fewer trees and poles in the C3 after IFMS implementation than in the $\mathrm{C} 1$ and the $\mathrm{C} 2$, and there were more saplings and seedlings. The number of saplings and seedlings in the $\mathrm{C} 3$ was increased dramatically than those in the $\mathrm{C} 2$ and $\mathrm{C} 1 \mathrm{~s}$. Large open area in the $\mathrm{C} 3$ has accelerated the growth of saplings and seedlings in the $\mathrm{C} 3$. Selective logging and intensive line planting significantly decreased forest canopy cover by reducing the number of trees. Canopy cover conditions in the catchment area are shown in Fig. 4. The percentage tree canopy cover was $80.1 \%$ in the $\mathrm{C} 1$ (Fig. 4a). Canopy cover decreased to $49.3 \%$ in the C3 (Fig. 4b). Thus, IFMS has decreased the canopy cover by approximately $38.5 \%$ [6].

\subsection{Hydrological characteristics}

Physical catchment parameters such as slope, circularity, main-stream slope, and drainage density affect stream flow and influence the shape of the hydrograph through catchment storage, runoff speed, infiltration, and soil water content. Catchment circularity contributes to the speed in which the surface runoff reaches the river channel. Circularity affects the bifurcation ratio, whether streams join the main channel successively or whether all tributaries have about the same length and feed water into the stream simultaneously thus creating a higher flood peak than in a long narrow catchment. Slope steepness contributes to accelerate the surface runoff flow to the downstream. A combination between circular shape and steeper slope contributes to the direct runoff amount and the increase in discharge to the peak at the catchment outlet. Greater drainage density appears to be associated with flashier runoff behaviour, greater total surface

Table 2: Vegetation structure of the three catchments.

\begin{tabular}{lcccc}
\hline & \multicolumn{4}{c}{ Individual amount per-hectare (N/ha) } \\
\cline { 2 - 5 } Catchment & Tree $^{\mathrm{a}}$ & Pole $^{\mathrm{b}^{*}}$ & Sapling $^{\mathrm{c}^{*}}$ & Seedling $^{\mathrm{d}^{*}}$ \\
\hline $\mathrm{C} 1$ & 212 & 208 & 1,027 & 690 \\
$\mathrm{C} 2$ & 153 & 181 & 1,472 & 8,600 \\
$\mathrm{C} 3$ & 113 & 152 & 3,226 & 18,433 \\
\hline
\end{tabular}

${ }^{a}$ Tree is vegetation with diameter $>20 \mathrm{~cm}$ (at $1.3 \mathrm{~m}$ above land surface).

bPole is vegetation with diameter $10-20 \mathrm{~cm}$.

'Sapling is vegetation with diameter $<10 \mathrm{~cm}$ and height $>1.5 \mathrm{~m}$.

${ }^{\mathrm{d}}$ Seedling is vegetation with height $<1.5 \mathrm{~m}$.

*The number of poles, saplings, and seedlings is calculated from the extrapolated of 25 subplots. 


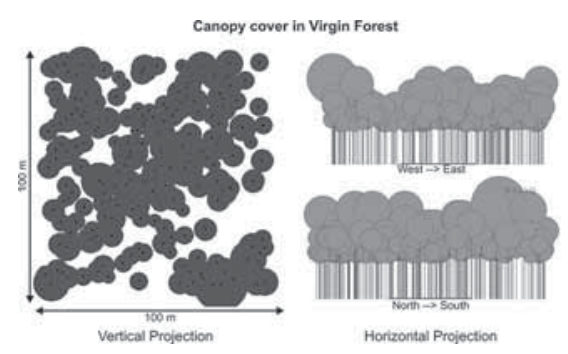

(a)

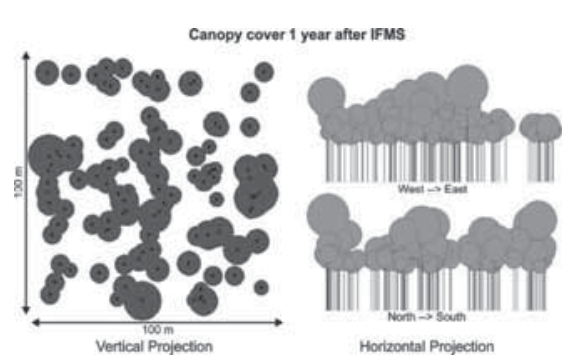

(c)

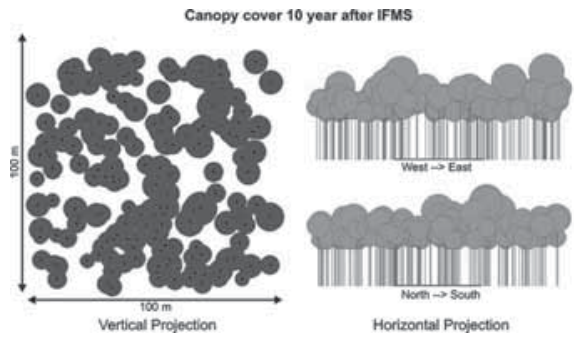

(b)

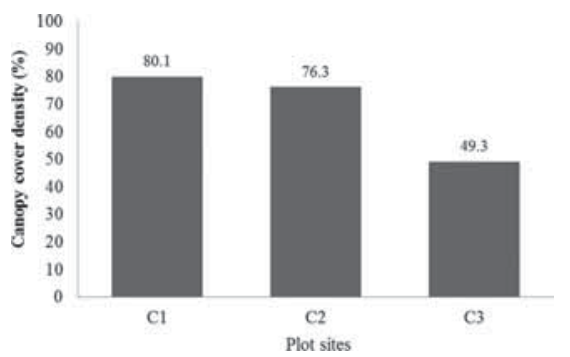

(d)

Figure 4: Tree canopy cover in C1 and after IFMS implementation. (a) C1, (b) C2, (c) C3, and (d) percentage of canopy cover density [6].

runoff, and less ground water storage. Main river length appears to be affecting the lag time and time concentration. A long main river produces longer time concentration and lower peak flow than that of a short main river. The hydrological behaviour of small catchments tends to be different from that of large catchments. A small catchment is very sensitive to high-intensity rainfall of short duration and to land cover characteristics [33]. The response of the runoff hydrograph to rainfall in the three catchments during a 1-year monitoring period (November 2010-October 2011) is shown in Fig. 5.

The $\mathrm{C} 1$ had a relatively constant base flow compared with the $\mathrm{C} 2$ and $\mathrm{C} 3$. The runoff hydrograph in the $\mathrm{C} 3$ produced the largest response to rainfall events. IFMS treatments lead to the formation of large canopy openings, resulting from tree felling, skid trails and haul roads constructions. A large open canopy in the $\mathrm{C} 3$ reduced the forest interception and transpiration, increasing net rainfall reaching the forest floor and may increasing the soil moisture. Different rainfall characteristics may affect different runoff hydrographs and peak discharge. Long duration of high rainfall intensity dominantly affects the higher peak discharge than that in the long duration of low intensity. Consequently, these conditions create a quick runoff response that was dominated by surface flow and increased the percentage of rainfall to runoff in the catchment (Fig. 5).

An individual rainfall event and a single runoff hydrograph at each catchment was selected during a 1-year monitoring period to clarify the direct runoff and peak discharge increase from base flow. The results showed that the $\mathrm{C} 3$ produced the highest direct runoff compared with the $\mathrm{C} 2$ and $\mathrm{C} 1$. In the small rainfall event $(<20 \mathrm{~mm})$, the $\mathrm{C} 1$ produced lower direct runoff than that in the $\mathrm{C} 2$ and $\mathrm{C} 3$ (Fig. 6a). In the medium rainfall event $(20-40 \mathrm{~mm}$ ), the $\mathrm{C} 2$ and $\mathrm{C} 3$ produced a similar direct runoff response, which was higher than that in the $\mathrm{C} 1$. In the large rainfall events $(>40 \mathrm{~mm}$ ), the $\mathrm{C} 3$ responded more strongly than the $\mathrm{C} 2$ and $\mathrm{C} 1$. Considering all rainfall events, the direct runoff in the $\mathrm{C} 1$ was lower than those in the $\mathrm{C} 2$ and $\mathrm{C} 3$. 

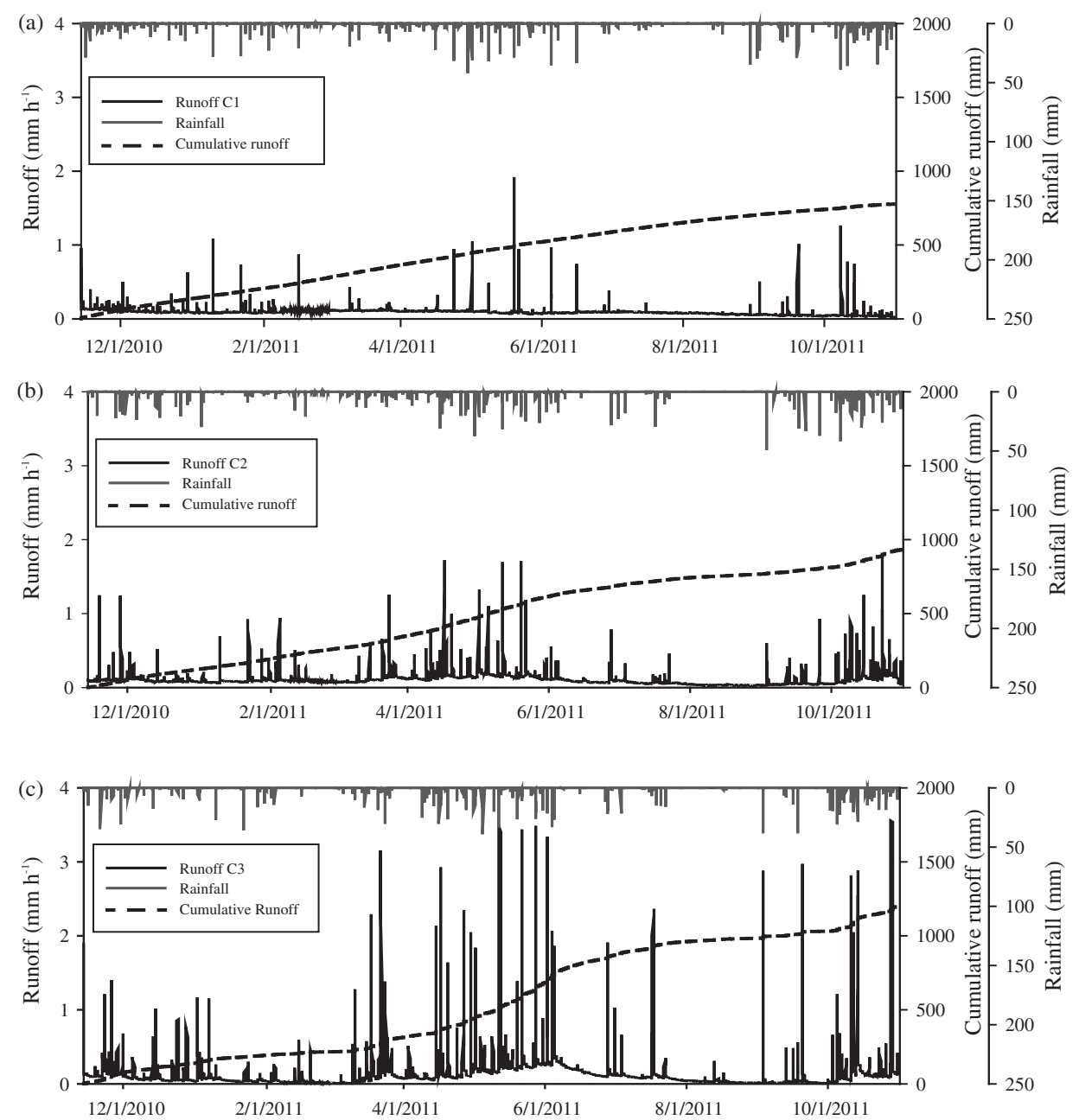

Figure 5: Relationship between rainfall and the runoff hydrograph: (a) C1, (b) C2, and (c) C3.

Figure 6 shows that no large differences were observed among the three catchments when the amount of rainfall to peak discharge and peak rainfall intensity was lower than $10 \mathrm{~mm}$. With increasing peak rainfall intensity, the increase in discharge from base flow to peak discharge was highest in the $\mathrm{C} 3$, followed by the $\mathrm{C} 2$ and then the $\mathrm{C} 1$. Reduced canopy cover in the $\mathrm{C} 3$ led to direct runoff. The relationships between the increase in discharge from base flow to peak discharge and the amount of rainfall to peak discharge, and peak rainfall intensity are shown in Fig. 7.

The scatter in discharge in the $\mathrm{C} 3$ is high in both amount and intensity of rainfall. $\mathrm{C} 3$ is more sensitive in response to rainfall characteristics (Fig. 7). Physical catchment characteristics of catchment circularity might contribute to the direct runoff and peak discharge responses. C3 has more circular shape than those in the $\mathrm{C} 2$ and $\mathrm{C} 1$ (Table 1). Circular shape contributes to the speed in which the surface runoff reaches the river channel. Large open areas in the $\mathrm{C} 3$ lead to greater net rainfall reaches on the forest floor and more trigger to produce surface runoff. A combination of circular shape and large open areas in the $\mathrm{C} 3$ lead to an increase in discharge from baseflow to the peak much higher than those in the $\mathrm{C} 2$ and $\mathrm{C} 1 \mathrm{~s}$. 

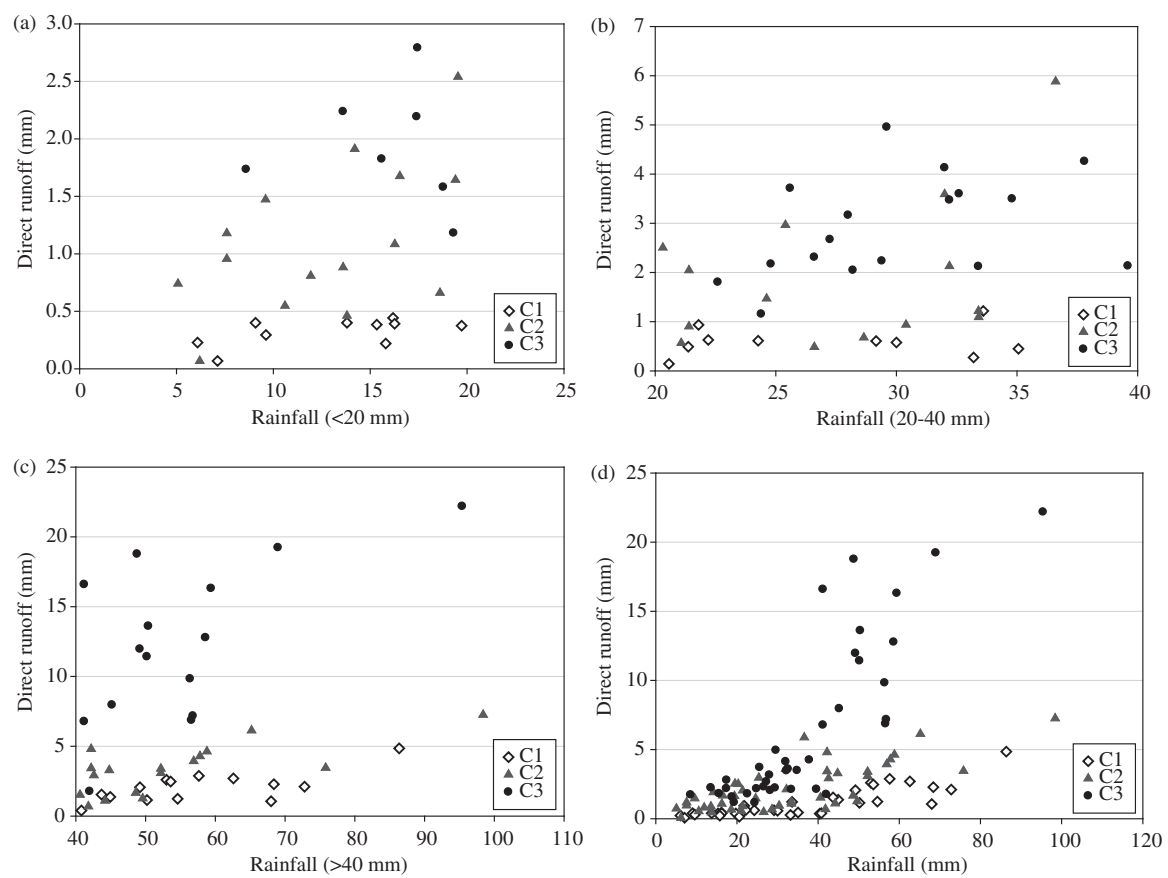

Figure 6: Direct runoff for different sizes of rainfall event. (a) Small rainfall events. (b) Medium rainfall events. (c) Large rainfall events. (d) All sizes rainfall events.
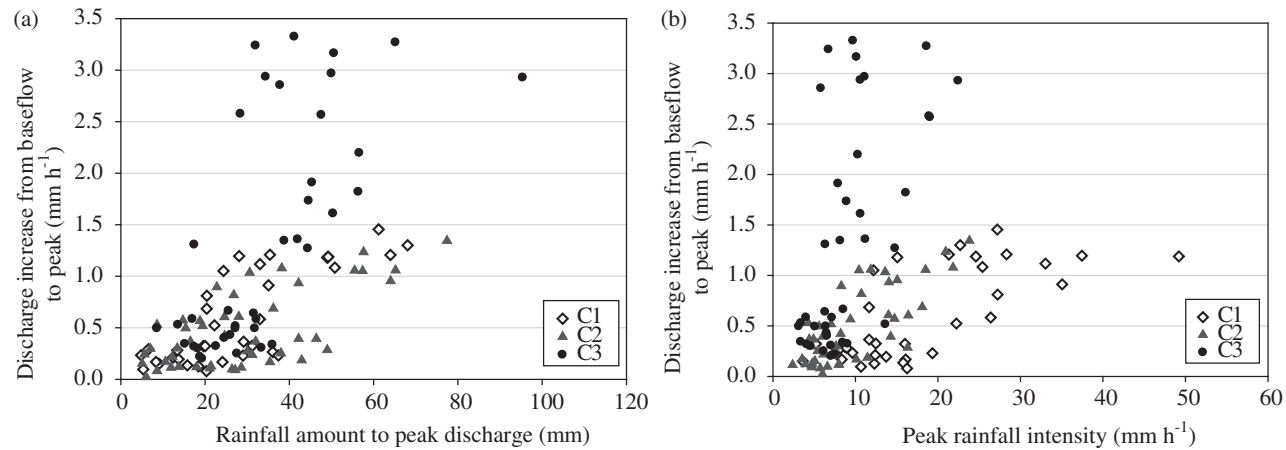

Figure 7: Relationship between the discharge increase from base flow to peak discharge and (a) rainfall amount to peak discharge and (b) peak rainfall intensity.

\subsection{Suspended sediment yield}

As shown in Fig. 8, treated forest in the C2 and C3s had higher SSC and SS flux than the undisturbed forest in the C1. The SSY is defined as the total sediment outflow from a catchment, measurable at a cross-section or outlet in a specified period. The SSYs of the three catchments during a 1-year monitoring period (November 2010-October 2011) are shown in Fig. 9. 

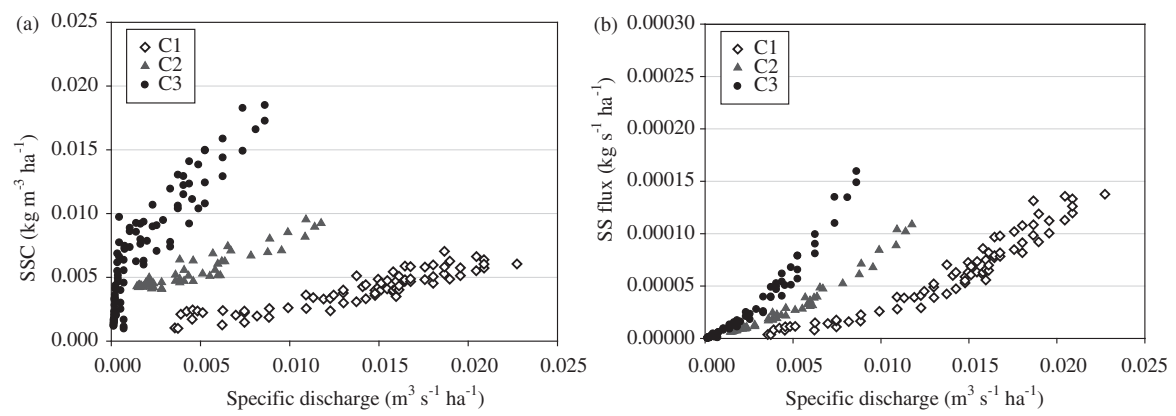

Figure 8: Suspended sediment in the three catchments. (a) Suspended sediment concentration (SSC) and (b) suspended sediment flux (SS flux).
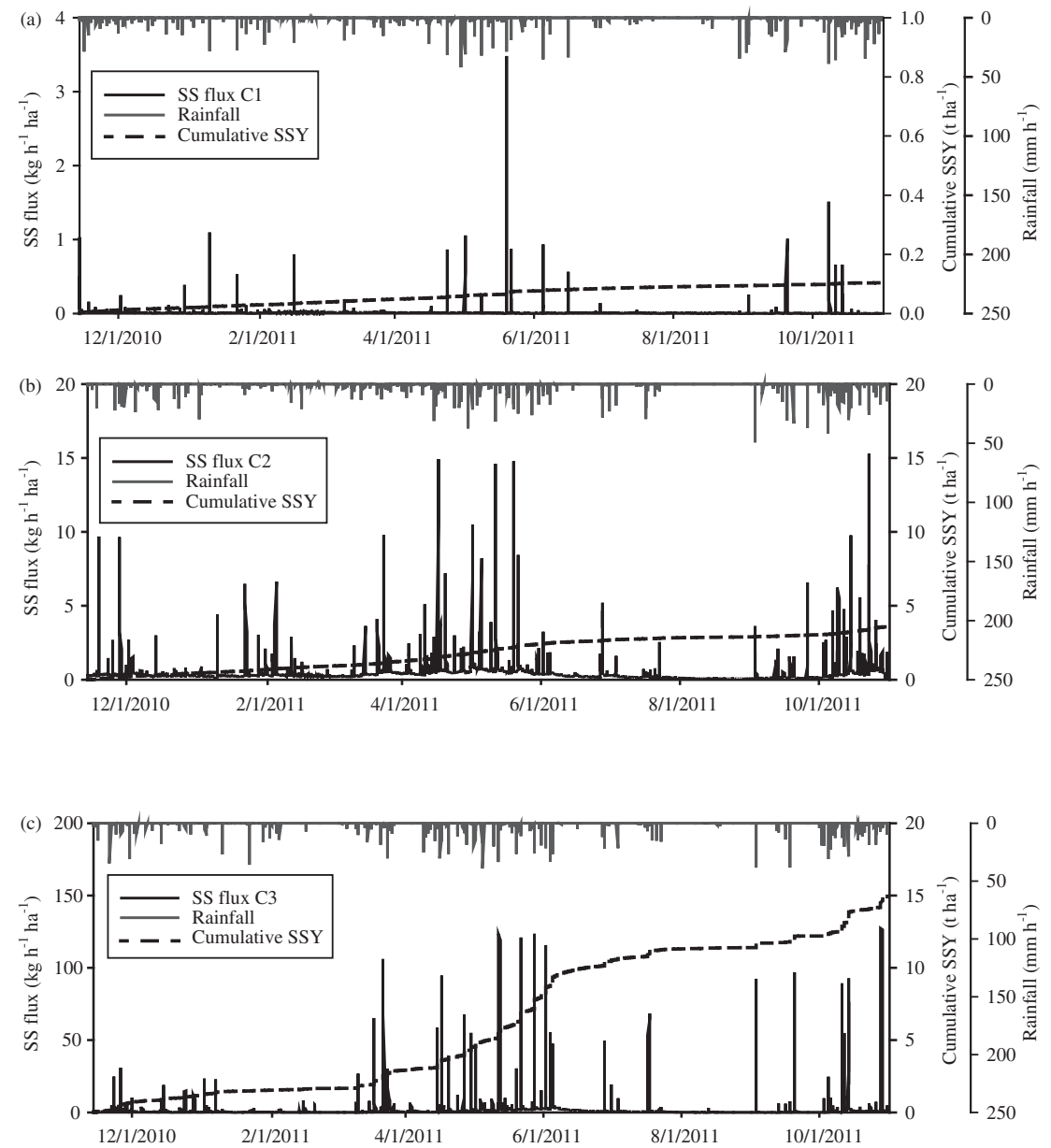

Figure 9: Suspended sediment flux (SS flux) and cumulative SSY. (a) C1, (b) C2, and (c) C3. 
Table 3: Total runoff and suspended sediment yield of the three catchments.

\begin{tabular}{lcccc}
\hline Catchment & $\begin{array}{c}\text { Total rainfall } \\
(\mathrm{mm})\end{array}$ & $\begin{array}{c}\text { Total runoff } \\
(\mathrm{mm})\end{array}$ & $\begin{array}{c}\text { Percentage of } \\
\text { runoff from } \\
\text { rainfall }(\%)\end{array}$ & $\begin{array}{c}\text { Total suspended } \\
\text { sediment yield } \\
\left(\mathrm{t} \mathrm{ha}^{-1} \mathrm{y}^{-1}\right)\end{array}$ \\
\hline $\mathrm{C} 1$ & 2,978 & 777 & 27 & 0.15 \\
$\mathrm{C} 2$ & 3,065 & 932 & 30 & 3.6 \\
$\mathrm{C} 3$ & 2,937 & 1,200 & 41 & 14.9 \\
\hline
\end{tabular}

Figure 9 shows that long duration of high rainfall intensity produced greater SS flux than that in the long duration of low rainfall intensity. High rainfall intensity potentially destructs the exposed bare soil, and the C3 had the largest SSY than those in the C2 and C1s (Fig. 9). The cumulative curves of SSY indicated that the C3 loads increased significantly after late March 2011. The largest sediment production occurred in late April until the beginning of the June 2011 period that experienced high rainfall events and produced higher runoff (Figs. 5c and 9c). During the monitoring period 1998-2012, the Environment Division of Sari Bumi Kusama company reported that there were no records of landslide events occurred in the three catchments. The results indicated that sediment yield in the $\mathrm{C} 2$ and $\mathrm{C} 3$ s dominantly comes from soil destruction by tractor machine during timber logging and log-hauling activities.

To clarify the impact of IFMS on the treated forest catchment, the annual water yield from cumulative runoff and the erosion yield from cumulative SSYs were analysed (Table 3). The annual water yield in the $\mathrm{C} 1, \mathrm{C} 2$, and $\mathrm{C} 3 \mathrm{~s}$ was $27 \%, 30 \%$, and $41 \%$ of annual rainfall, respectively. The erosion yields were $0.15,3.6$, and $14.9 \mathrm{tha}^{-1} \mathrm{y}^{-1}$, respectively.

\section{DISCUSSION}

\subsection{Effect of the IFMS on runoff responses}

A change in land use in a catchment may lead to changes in its water balance. The response time of stream flow is generally determined by climate (mostly rainfall), vegetation characteristics, catchment properties, and vegetation management practices [33]. The forest canopy serves as a barrier against precipitation reaching the ground. Selective logging activity using tractors has opened and destroyed approximately $4-6 \%$ of the soil surface of the forested area by creating skid trails and a further $60-75 \%$ by pulling logs using a tractor winch. Manual land clearing for intensive line planting has opened approximately $15-20 \%$ of the forested area in the study catchment.

Growth of vegetation in the $\mathrm{C} 2$ (Table 2) increased canopy interception and forest floor retention. For small rainfall events, most precipitation was trapped by the canopy in the $\mathrm{C} 1$ and $\mathrm{C} 2 \mathrm{~s}$, leading to negligible direct runoff responses to rainfall (Fig. 6b). Although the canopy cover in the $\mathrm{C} 2$ became almost the same as that in the $\mathrm{C} 1$ (Fig. 3), canopy interception and evapotranspiration rates were slightly lower than that in the $\mathrm{C} 1$. These conditions led to still higher net precipitation in the $\mathrm{C} 2$. For small, medium, and large rainfall events, the net precipitation in the $\mathrm{C} 1$ and $\mathrm{C} 2 \mathrm{~s}$ was still lower than in the $\mathrm{C} 3$. In the $\mathrm{C} 3$ with a low canopy cover density, there was a large net precipitation and increased amounts of direct runoff. The high canopy cover density in undisturbed areas controlled the net precipitation by canopy interception and evapotranspiration. 
In addition to the rainfall interception due to canopy cover, catchment topography also affected the runoff, particularly in response to the increase in discharge from base flow to peak discharge. Catchment circularity, drainage density, catchment slope and main-river slope were affects how quickly surface and subsurface runoff reach the outlet of catchment. The highest increase in discharge from base flow to peak discharge was in the C3 (Fig. 7). The higher circular shape and drainage density in the $\mathrm{C} 3$ (Table 1) affected the rapidity with which water could flow to the catchment outlet. The circular shape may have concentrated rainwater towards the catchment outlet faster than that of a non-circular catchment. The $\mathrm{C} 3$ with a circular shape may have accumulated all runoff in the catchment outlet at the same time, leading to a fast peak time, and an increase in peak discharge. Catchments with steep slopes also had the potential to deliver rainwater to catchment outlets. The rapid response of the increase in discharge from base flow to peak discharge in the $\mathrm{C} 1$, similar to the C3 (Fig. 7a), may have been influenced by the catchment slope. The increase in discharge from base flow to peak discharge in the $\mathrm{C} 2$ with a non-circular and lower slope was the smallest of all catchments (Fig. 7b).

The changes in soil characteristics by selective logging activities are also important factors for hydrological processes. Selective logging significantly increased the soil compaction and reduced the infiltration capacity, particularly in the skid trails. The removal of vegetation by mechanized and manual means has changed the hydraulic properties of soils. The water impeding layers in the soil surface can reduce the soil infiltration and yield surface runoff, which affects the volume of direct runoff. As the proportion of precipitation that occurs as surface runoff increased, the volume of direct runoff and the rate of flow to the catchment outlet increased. Although the recovery of forest floor vegetation in the $\mathrm{C} 3$ may reduce the surface runoff, considering the results above, the effects of total open area and soil characteristic changes are important for runoff responses. Therefore, the $\mathrm{C} 3$ responded quickly to rainfall and produced an annual water yield of $41 \%$ of the total annual rainfall; Table 3).

Logged forest had less canopy cover, compacted soils, and low infiltration capacities. Consequently, these conditions reduced the forest interception, evapotranspiration, and infiltration volumes, creating a quick runoff response that was dominated by surface runoff and increased the percentage of rainfall to runoff in the catchment. With the effect of catchment topography in the forested catchments, the change of forest cover and destruction of soils are the dominant factors impacting runoff responses.

\subsection{Effect of IFMS on soil erosion}

Erosion is one of the most serious problems in the Kalimantan tropical rainforest. Soil organic matter in the Kalimantan forest is very shallow at about 2-5 cm [27]. Ruslan and Manan [23] reported that erosion and surface runoff decreased after skidding roads were abandoned in South Kalimantan, and that trees, grasses, and shrubs re-colonized the bare ground. However, such secondary forest cover neither protects soil in the same manner that primary forest does nor is able to easily compensate for the physical damage already done to the soil (i.e. compaction, loss of soil structure, and removal of organic litter) [18]. Hartanto et al. [22] reported runoff and soil erosion in Central Kalimantan using plot-level monitoring. The presence of organic forest floor materials, such as a litter layer and woody debris, is very important for preventing soil detachment in the control and harvest plots and providing surface roughness, thus reducing runoff and soil particle movement downslope. The absence of soil cover and surface roughness at the skid trail plots increased runoff and soil detachment by raindrops and provided unobstructed movement of runoff and soil particles downslope. 
The use of selective logging and intensive line planting has dramatically changed the vegetation structure, soil properties, and infiltration capacity of the study area. These changes were compounded because of the fragile Ultisol of the humid tropics. In the humid tropics, poor soil cohesion, high rainfall, and high temperatures give rise to highly erosive soils that are very sensitive to the impacts of heavy machinery and cleared vegetative cover [21,22,33,34]. Furthermore, Ultisol is acidic and its acidity decreases with soil depth, making it more susceptible to disruption. These soil characteristics made the study area more sensitive to logging and line planting, which in turn augmented runoff and erosion. High rainfall intensity leads to high rainfall erosivity, as the organic soil layer is easily eroded, decreasing soil fertility. Once a forest or even a small patch of forest is cleared, organic matter within the soil is quickly lost. With the disappearance of soil organic matter, the ability of the soil to recycle nutrients is also quickly lost, soil fertility rapidly declines, and the ecosystem loses its productive capacity [13,35]. Erosion control initiatives should be implemented as part of the clearing process, followed by vegetation restoration immediately to cease the disturbance.

Previous studies have reported that reduced rain splash due to vegetation cover leads to less soil loss $[17,20]$. The high canopy-cover density in the $\mathrm{C} 2$, which was close to that of $\mathrm{C} 1$, may have intercepted more rain, thus reducing rain splash and soil loss. Indeed, the annual SSY in the C2 was $3.6 \mathrm{tha}^{-1} \mathrm{y}^{-1}$ (Table 3) higher than that in the $\mathrm{C} 1\left(0.15 \mathrm{t} \mathrm{ha}^{-1} \mathrm{y}^{-1}\right)$. C1 had the higher catchment slope compared with C2 (Table 1). This characteristic may produce higher SSY that come from surface erosion of the steeper slope in the $\mathrm{C} 1$ than in C2. However, the SSY investigation showed that the C2 had higher annual SSY than in the C1 (Fig. 9 and Table 3). These results indicated that the C2 with similar canopy cover conditions after forested managements still yielded more suspended sediment relative to the virgin forest. This suggests that not catchment topographical characteristics but forested managements (land use) directly affected the SSY. A previous study reported an SSY of 4.1-6.85 $\mathrm{t} \mathrm{ha}^{-1} \mathrm{y}^{-1}$ in disturbed dry dipterocarp forest in Mae Thaang, Thailand [16]. Other catchments in Sarawak Malaysia that were logged 10 years previously had a lower soil loss of $0.11-0.36 \mathrm{t}$ $\mathrm{ha}^{-1} \mathrm{y}^{-1}[16]$. These results show that the changes in forest cover and soil physical properties significantly affect the runoff response to rainfall, particularly regarding soil erosion and sediment discharges into the stream channel.

The degree to which the canopy affects erosion depends on the percent of the forest floor covered by the understory and the density of the canopy [11]. More understory vegetation and a denser canopy cover lead to greater rainfall interception and retention. Although canopy density in the $\mathrm{C} 3$ was lower than that in the $\mathrm{C} 2$, the former had more understory vegetation, leading to more forest floor interception. Although the $\mathrm{C} 3 \mathrm{had}$ more understory vegetation, the annual sediment yield was still high (Table 3). Commercial logging with road construction has created new routes for surface runoff. Roadside drainage and gullies have been developed by bank erosion and operate as part of the channel sediment supply. Steep slopes along roads and on mounds of weathered material produced by tractors during logging activities provide potential sediment sources. Line clearing patterns for intensive line planting often cut the contours and may produce rill erosion.

SSC was higher in the $\mathrm{C} 3$ and $\mathrm{C} 2 \mathrm{~s}$ than in the $\mathrm{C} 1$ (Fig. 8a). The amount of SSC in the stream channel affected the amount of SS flux. High SSC in the C3 produced a high SS flux (Fig. 8b). Annual SSY in the C1 was $0.15 \mathrm{t} \mathrm{ha}^{-1} \mathrm{y}^{-1}$ (Table 3). Compared with data from other undisturbed forest catchments, the SSY of C1 was estimated to be low. A study on three catchments in Thailand (Huai Bo Thong, Lam Thakhong, and Kogma) indicated that sediment yields from undisturbed forests range from $0.06 \mathrm{tha}^{-1} \mathrm{y}^{-1}$ in mixed deciduous forest to $0.35 \mathrm{t} \mathrm{ha}^{-1} \mathrm{y}^{-1}$ in hill evergreen forest [16]. Soil loss in the primary forest of Sarawak Malaysia is $0.8-0.31 \mathrm{t} \mathrm{ha}^{-1} \mathrm{y}^{-1}$ [16]. Studies on four 
forested catchments in Malaysia (Cameron Highlands, Johor, Selangor, and Ulu Segama) have reported sediment yields of $0.41-3.12 \mathrm{t} \mathrm{ha}^{-1} \mathrm{y}^{-1}[36,37]$. SSY in a tropical rain forest of Panama was reported to be $2.04 \mathrm{tha}^{-1} \mathrm{y}^{-1}$ [38].

In the present study, annual SSY in the C3 was $14.9 \mathrm{t} \mathrm{ha}^{-1} \mathrm{y}^{-1}$ (Table 3) and the difference between $\mathrm{C} 1$ and C3 was $14.75 \mathrm{t} \mathrm{ha}^{-1} \mathrm{y}^{-1}$. SSY observations in Ulu Segama, Malaysia, after road construction and commercial logging increased to $16 \mathrm{tha}^{-1} \mathrm{y}^{-1}$ and the increase from undisturbed to disturbed catchments was $12.88 \mathrm{t} \mathrm{ha}^{-1} \mathrm{y}^{-1}$ [15]. It is possible that the rates of erosion vary in different rainforest types in relation to the differences in rates of rainfall, interception, and the nature of the ground cover. Although the values cannot be compared directly, the results suggest that an IFMS producing a large open forest area will produce high soil erosion yields. A management strategy is required to control the runoff and soil erosion.

\section{CONCLUSIONS AND RECOMMENDATIONS}

The effect of the IFMS on the hydrological responses in a tropical Indonesian rainforest was investigated using three different forested catchment experiments. The IFMS is an important factor in the catchment hydrology and forest management. The IFMS has increased in large scale of open forest and exposed the bare soil, especially in the early years after forest operation. This condition has changed drastically in the catchment hydrologic responses. The data provide strong linkages between IFMS treatments and direct runoff-soil erosion response. There was more direct runoff in the $\mathrm{C} 3$ than in the $\mathrm{C} 2$ and $\mathrm{C} 1 \mathrm{~s}$. The percentage of annual rainfall that became runoff in the $\mathrm{C} 1, \mathrm{C} 2$, and $\mathrm{C} 3 \mathrm{~s}$ were $27 \%, 30 \%$, and $41 \%$, respectively. In the natural conditions of the $\mathrm{C} 1,27 \%$ of annual rainfall became runoff and the rest became groundwater or was evapotranspired. The annual SSY in the $\mathrm{C} 1, \mathrm{C} 2$, and $\mathrm{C} 3 \mathrm{~s}$ was $0.15,3.6$, and $14.9 \mathrm{t} \mathrm{ha}^{-1} \mathrm{y}^{-1}$, respectively. This study demonstrated that direct runoff and sediment yield increased dramatically during the early years after IFMS implementation. The results showed that the magnitude of runoff and soil erosion depends on the interaction among the rainfall, forest cover changes, forest treatment applied, and catchment characteristics. Ten years after forest operation, forest cover has recovery close to natural condition, but still there are differences in hydrological response. Forest cover recovery decreased direct runoff and soil erosion significantly. Proper protection of the forest floor with an understory would also contribute in controlling the direct runoff and soil erosion.

Forest managers implementing the IFMS in tropical rainforests should consider changes in peak discharge, direct runoff, and soil erosion, particularly during the early years after selective logging and intensive line planting. A proper monitoring system would allow more direct associations to be made between management practices and their impacts, thereby enabling managers to identify problems and take appropriate preventive measures to improve management. The recommendation to control runoff and soil erosion from logging activities in a tropical Indonesian rainforest should be implemented to reduce the impact of logging techniques and combine ecologically based vegetation structure design.

\section{REFERENCES}

[1] Nussbaum, R. \& Hoe, A.L., Rehabilitation of degraded sites in logged-over forest using Dipterocarps. Dipterocarps Forest Ecosystem. Towards Sustainable Management, eds. A. Schulte \& D. Schone, World Scientific Publishing: Singapura, pp. 446-463, 1996. doi: http://dx.doi. org/10.1142/9789814261043_0020 
[2] Nussbaum, R., Anderson, J. \& Spencer, T., Planting Dipterocarps for rehabilitation of log landings and skid trails in Sabah, Malaysia. Proceedings of the Fifth Round-Table Conference on Dipterocarps, eds. S. Appanah \& K.C. Khoo, Chiang Mai, pp. 299-315, 1996.

[3] Bruijnzeel, L.A., Managing tropical forest watersheds for production: where contra-dictionary theory and practice co-exist. Wise Management of Tropical Forests, Oxford Forestry Institute: Oxford, UK, pp. 37-75, 1992.

[4] Van Der Plas, M.C. \& Bruijnzeel, L.A., Impact of mechanized selective logging of rainforest on topsoil infiltrability in the upper segama area, Sabah, Malaysia. Hydrology of Warm Humid Regions. IAHS Publ. no. 216, pp. 203-211. 1993.

[5] Osuji, G.E., Okon, M.A., Chukwuma, M.C. \& Nwarie, I.I., Infiltration characteristics of soils under selected land use practices in Owerri, Southeastern Nigeria. World Journal of Agricultural Sciences, 6(3), pp. 322-326, 2010.

[6] Suryatmojo, H. The effect of line planting toward infiltration. Proceeding of International Seminar "Research on Plantation Forest Management : Challenges and Opportunities," Bogor. 2009.

[7] Cosandey, C., Andreassian, V., Martin, C., Didon-Lescot, J.F., Lavabre, J., Folton, N., Mathys, N. \& Richard, D., The hydrological impact of the Mediterranean forest: a review of French research. Journal of Hydrology (Amsterdam), 301(1), pp. 235-249, 2005. doi: http://dx.doi. org/10.1016/j.jhydrol.2004.06.040

[8] Chaves, J., Neill, C., Gemer, S., Neto, S.G., Krusche, A. \& Elsenbeer, H., Land management impacts on runoff sources in small Amazon watersheds. Hydrological Processes, 22(12), pp. 1766-1775. 2008. doi: http://dx.doi.org/10.1002/hyp.6803

[9] Huang, M., Zhang, L. \& Gallichand, J., Runoff responses to afforestation in a watershed of the Loess Plateau, China. Hydrological Processes, 17(13), pp. 2599-2609, 2003. doi: http:// dx.doi.org/10.1002/hyp.1281

[10] Moody, J.A. \& Martin, D.A., Post-fire, rainfall intensity-peak discharge relations for three mountainous watersheds in the Western USA. Hydrological Processes, 15, pp. 2981-2993, 2001. doi: http://dx.doi.org/10.1002/hyp.386

[11] Toy, T.J., Foster, G.R. \& Renard, K.G., Soil Erosion: Processes, Prediction, Measurement, and Control, John Wiley \& sons, Inc.: New York, pp. 25-52, 2002.

[12] Klöcking, B. \& Haberlandt, U., Impact of landuse changes on water dynamics-a case study in temperate Meso and Macroscale river basin. Physics and Chemistry of the Earth, 27, pp. 619-629, 2002. doi: http://dx.doi.org/10.1016/s1474-7065(02)00046-3

[13] Montagnini, F. \& Jordan, C.F., Tropical Forest Ecology. The Basis for Conservation and Management, Springer: The Netherlands, pp. 40-53, 2005.

[14] Robinson, M., Cognard-Plancq, A.L., Cosandy, C., David, J., Durand, P., Fuhrer, H.W., Hall, R., Hendriques, M.O., Marc, V., McCarthy, R., McDonnell, M., Martin, C., Nisbet, T., O’Dea, P., Rodgers, M. \& Zollner, A., Studies of the impact of forest on peak flows and baseflows: a European perspective. Forest Ecology and Management, 186, pp. 85-97, 2003. doi: http:// dx.doi.org/10.1016/s0378-1127(03)00238-x

[15] Douglas, I., Spencer, T., Greer, T., Bidin, K., Sinun, W. \& Meng, W.W., The impact of selective commercial logging on stream hydrology, chemistry and sediment loads in the Ulu Segama rain forest, Sabah, Malaysia. Philos. Philosophical Transactions of The Royal Society B: Biological Sciences, 335, pp. 397-406. 1992. doi: http://dx.doi.org/10.1098/rstb.1992.0031

[16] Douglas, I., Hydrological investigations of forest disturbance and land cover impacts in SouthEast Asia: a review. The royal society. Philosophical Transactions of the Royal Society of London B, 354, pp. 1725-1738. 1999. doi: http://dx.doi.org/10.1098/rstb.1999.0516 
[17] Douglas, I., Predicting road erosion rates in selectively logged tropical rain forests. Proceedings of Symposium HSO1 held during IUGG2003 at Sapporo, July 2003. IAHS Publ. no. 279, pp. 199-205. 2003.

[18] Stadtmueller, T., Soil erosion in East Kalimantan, Indonesia. Proceedings of the Fiji Symposium. IAHS-AISH Publ. No. 192, pp. 221-230. 1990.

[19] Abdulhadi, R., Kartawinata, K. \& Sukardjo, S., Effects of mechanized logging in the Lowland Dipterocarps Forest at Lempake, East Kalimantan. The Malaysian Forester, 44, pp. 407-418, 1981.

[20] Anderson, S., Logging and soil erosion: an examination of the effects of logging on soil erosion in the rain forest of Ulu Segama, Eastern Sabah. BSc Dissertation. University of Manchester: Manchester, UK, 1990.

[21] Hendrison, J., Damage-controlled logging in managed tropical rainforest in suriname. $\mathrm{PhD}$ thesis, Agricultural University Wageningen: The Netherlands, 1990.

[22] Hartanto, H., Prabhu, R., Widayat, A.S.E. \& Asdak, C., Factors affecting runoff and soil erosion: Plot-level soil loss monitoring for assessing sustainability of forest management. Journal of Forest Ecology and Management, 180(1-3), pp. 361-374, 2003. doi: http://dx.doi. org/10.1016/s0378-1127(02)00656-4

[23] Ruslan, M. \& Manan, S., The effect of skidding roads on soil erosion and runoff in the forest concession of Pulau Laut, South Kalimantan, Indonesia. (in Indonesia language). Proceeding of Seminar on Hydrology and Watershed Management, Surakarta, Indonesia, pp. 169-194, 1980.

[24] Suryatmojo, H., Kosugi, K., Mizuyama, T., Nugroho, P. \& Hakim, A.R., Water balance in tropical rain forest with selective cutting and line planting treatment. Proceeding of International Conference "Sustainable Future for Human Security," Kyoto University: Japan, pp.450-459, 2010.

[25] Suryatmojo, H., Fujimoto, M., Kosugi, K. \& Mizuyama, T., Impact of selective logging and intensive line planting system on runoff and soil erosion in a tropical Indonesia rainforest. Proceedings of River Basin Management VI. Wessex Institute of Technology: UK, pp. 288-300, 2011. doi: http://dx.doi.org/10.2495/rm110251

[26] Schmidt, F.H. \& Ferguson, J.H.A., Rainfall types based on wet and dry period ratios for Indonesia with Western New Guinea. Verh. Djawatan Met. Dan Geofisik. Djakarta 42, 1951.

[27] Widiyatno, Suryatmojo, H. \& Purnomo, S., Prelimenary evaluation of soil fertility status at silviculture system “Tebang Pilih tanam Indonesia (TPTII)" at PT Sari Bumi Kusuma. Research Report (unpublished). Faculty of Forestry, Gadjah Mada University, Yogyakarta, Indonesia, 2010.

[28] Na'iem, M. \& Faridah, E., Model of intensive enrichment planting (TPTII). Silviculture Systems of Indonesia's Dipterocarps Forest Management a Lesson Learned, ed. A. Rimbawanto, Faculty of Forestry Gadjah Mada University and ITTO. Technical Report: ITTO Project PD 41/00 Rev. 3 (F,M), pp. 25-36, 2006.

[29] Gordon, N.D., McMahon, T.A. \& Finlayson, B.L., Stream Hydrology. An Introduction for Ecologists, Wiley: Chichester, pp. 100-117, 1992. doi: http://dx.doi.org/10.1002/aqc.3270030107

[30] Nolan, K.M., Gray, J.R. \& Glysson, G.D., Introduction to suspended-sediment sampling. Scientific Investigations Report 2005-5077, U.S. Geological Survey. 2005.

[31] Nussbaum, R., Anderson, J. \& Spencer, T., Planting dipterocarps for rehabilitation of log landings and skid trails in Sabah, Malaysia. Proceedings of the Fifth Round-Table Conference on Dipterocarps, eds. S. Appanah \& K.C. Khoo, Chiang Mai, pp. 299-315, 1996.

[32] Chang, M., Forest Hydrology, An Introduction to Water and Forests, 2nd edn., CRC Press: USA, pp. 201-2010. 2006. 
[33] Brown, A.E., Zhang, L., McMahon, T.A., Western, A.W. \& Vertessy, R.A., A review of paired catchment studies for determining changes in water yield resulting from alterations in vegetation. Journal of Hydrology (Amsterdam), 310, pp. 28-61, 2005. doi: http://dx.doi. org/10.1016/j.jhydrol.2004.12.010

[34] Huang, C. \& Laflen, J.M., Seepage and soil erosion for a clay loam soil. Soil Science Society of America Journal. 60, pp. 408-416, 1996. doi: http://dx.doi.org/10.2136/ sssaj1996.03615995006000020011x

[35] Lal, R., Deforestation of tropical rainforest and hydrological problems. Tropical Agricultural Hydrology, eds. R. Lal \& E.W. Russell, Wiley: New York, pp. 131-140, 1981.

[36] Jordan, C.F., Nutrient Cycling in Tropical Forest Ecosystems, Wiley: Chichester, 1985. doi: http://dx.doi.org/10.1017/s0376892900011772

[37] Sayer, A.M., Walsh, R.P.D. \& Bidin, K., Pipeflow suspended sediment dynamics and their contribution to stream sediment budgets in small rainforest catchments, Sabah, Malaysia. Forest Ecology and Management, 224, pp. 119-134, 2006. doi: http://dx.doi.org/10.1016/j. foreco.2005.12.012

[38] Sinun, W., Meng, W.W., Douglas, I. \& Spencer, T., Throughfall, stemflow, overland flow and throughflow in the Ulu Segama rain forest, Sabah, Malaysia. Philosophical Transactions of the Royal Society B: Biological Sciences, 335, pp. 389-395, 1992. doi: http://dx.doi.org/10.1098/ rstb.1992.0030

[39] Zimmermann, A., Francke, T. \& Elsenbeer, H., Forest and erosion: insights from a study of suspended-sediment dynamics in an overland flow-prone rainforest catchment. Journal of Hydrology, 428-429, pp. 170-181, 2012. doi: http://dx.doi.org/10.1016/j.jhydrol.2012.01.039 